\title{
Competence of Croatian Student-Teachers and Primary School Teachers in the Visual Arts
}

Zlata Tomljenović ${ }^{\star 1}$ And Svetlana Novaković ${ }^{2}$

$\approx$ In visual arts education, specific competences pertain to having knowledge from the theory and praxis of visual arts and the teaching methodology of visual arts. The goal of this research was to examine the opinions of 231 students of graduate teacher studies and 143 in-service primary school teachers about the importance of specific competences in the visual arts, as well as the level of achieving the stated competences during studies. The frequency of teachers attending various forms of professional training in the visual arts was also examined. Two questionnaires were designed for the research. The data obtained with the questionnaires were processed at the level of descriptive and inferential statistics. A Wilcoxon Signed Ranks Test was used to compare the differences in the arithmetic means between the perception of importance and the perception of possessing the competences between these two groups. The research has shown the existence of a statistically significant difference between the self-assessment about the importance of specific competences in the visual arts, and the self-assessment of having these competences, both with students of the Croatian faculties of teacher education and primary school teachers. The results also have shown the insufficient presence of teachers' further professional training in the visual arts area.

Keywords: competence, primary school teachers, professional training, student-teachers, subject-specific competences, visual arts education

$1 \quad{ }^{*}$ Corresponding Author. Faculty of Teacher Education, University of Rijeka, Croatia; zlata.tomljenovic@ufri.uniri.hr.

2 Faculty of Teacher Education, University of Zagreb, Croatia. 


\section{Kompetence hrvaških študentov pedagoških smeri in osnovnošolskih učiteljev likovne vzgoje}

Zlata Tomljenović in Svetlana Novaković

$\approx$ V likovni vzgoji se specifične kompetence nanašajo na znanje iz teorije in prakse likovne umetnosti ter na metodologijo poučevanja likovne umetnosti. Cilj raziskave je bil preučiti mnenja 231 študentov pedagoške smeri in 143 osnovnošolskih učiteljev o pomembnosti specifičnih kompetenc $\mathrm{v}$ likovni umetnosti ter stopnjo doseganja navedenih kompetenc med študijem. Prav tako smo preučili, kako pogosto se učitelji udeležujejo različnih oblik strokovnega usposabljanja na področju likovne umetnosti. Za namene raziskave sta bila sestavljena dva vprašalnika. Pridobljeni podatki so bili obdelani na ravni deskriptivne in inferenčne statistike. Za primerjavo razlik $\mathrm{v}$ aritmetičnih sredinah med zaznavanjem pomembnosti in dojemanjem posedovanja kompetenc med tema skupinama je bil uporabljen Wilcoxonov test vsote rangov. Raziskava je pokazala obstoj statistično pomembne razlike med samooceno o pomembnosti specifičnih kompetenc $\mathrm{v}$ likovni umetnosti in samooceno posedovanja teh kompetenc pri študentih pedagoške smeri na Hrvaškem ter pri osnovnošolskih učiteljih.

Ključne besede: kompetence, osnovnošolski učitelji, strokovno usposabljanje, študentje pedagoške smeri, predmetno specifične kompetence, izobraževanje na področju likovne umetnosti 


\section{Introduction}

Today, formal education and teachers' professional development are directed towards gaining competences, which pervades over the obsolete pedagogical paradigm of teaching as information transference. The teacher should possess competences that encompass not only routine knowledge transference, but also significantly more complex knowledge, abilities, and decision making. The aforementioned competences refer to the responsible designing of the teaching process, to seeking creative ways of its implementation, to quick and efficient adapting to dynamic and unforeseen teaching situations, to motivating the pupils' independent and creative art expression, using new technologies and stimulating integral (cognitive, affective, and psycho-motor) development of the pupils' personality (Bamford, 2006; Efland, 2002; Eisner, 2002). Teachers acquire qualifications for these competences during their professional education. However, this is not enough since rapid social and educational changes have created the need for constant improvement through the expanding and deepening of professional knowledge, i.e., through acquiring new competences which teachers gain through lifelong learning (Hudson \& Hudson, 2007; Valenčič Zuljan, 2001). Development of professional competences should be stimulated in initial, as well as in further professional teachers' education (Craft, 2000).

Apart from the general pedagogic and psychological, as well as didactic and methodical competences, the teachers' professional development includes the acquisition of certain subject-specific competences related to particular disciplines, i.e., school subjects. In visual arts, as a school subject, these competences include the knowledge of theory and history of visual arts, knowledge of visual arts pedagogy, knowledge of the specifics of the teaching process, knowledge about the purpose, goals and tasks of visual arts as a school subject, the ability to recognise and understand the pupils' individual and art specifics and their ways of learning, the ability to adjust to one's own knowledge and capacities to new situations, and the ability to apply an open and reflexive way of teaching (Burnard \& Hennessy, 2006; Marshall, 2005).

\section{Development of competences in visual arts in teacher education studies}

The reform of higher education started in Croatia with the signing of the Bologna Declaration in 2001, and in the 2005/2006 academic year, the first generation of 'Bologna students' enrolled at the Croatian faculties (Domović \& 
Vizek Vidović, 2010). The concepts of the Bologna Declaration have also been implemented in current educational concepts in the visual arts following acceptance of the European standards for teachers' competences and qualifications (Zgaga, 2007). These concepts are also reflected in the context of higher education in the Republic of Croatia based on the competence approach to higher education (competence-based curriculum), which provides a broader definition of learning results than restricting them to mere information acquisition: they are directed towards the competences that a student needs to develop throughout the course of his or her study (Lončarić \& Pejić Papak, 2009; Muršak, 2001; Vizek Vidović, 2009). In accordance with the Bologna Declaration Guidelines, at the faculties of teacher education in Croatia today, integrated undergraduate and graduate studies for the education of teachers in primary education are carried out over five years. When discussing the subjects related to visual arts, i.e., the methodology of visual arts education at Croatian faculties, the programmes are somewhat different in terms of comprehensiveness, i.e., the number of subjects connected to the area. However, they correspond with the foreseen learning results, i.e., with the competences that a student should acquire in the course of his or her studies. It can be stated that, within the framework of these programmes, students are empowered to gain art and pedagogic knowledge, skills and standpoints, which are shaped on the basis of visual arts-theoretical and practical experiences, and which a student, in accordance with his or her abilities, integrates and uses in a certain teaching situation (Tacol, 2006).

The modern concept of visual arts education corresponds to Perrenoud's (2002) understanding of gaining competence in terms of a person's training for the usage and integration of the acquired knowledge in complex, different, and unforeseen situations. In making and implementing faculty programmes for visual arts education methodology, the process of acquiring general pedagogic and psychological, as well as didactic and methodological competences, should be harmonised with the acquisition of professional, i.e., subject-specific competences (Razdevšek Pučko \& Rugelj, 2006). It is essential to observe the student-teachers' competences in visual arts classes in the context of achieving the purpose of visual arts education, which means that student-teachers should know the goals, results of learning and general standards of the subject (Barton, Baguley, \& MacDonald, 2013). The importance of the acquisition of subjectspecific competences in the context of teaching visual arts has been confirmed by a recent survey (Podobnik, 2011) in which it is stated that an adequate quality of teaching cannot be reached without their development.

Apart from the cognitive aspect, gaining competences also includes the 
motivational and emotional aspects of doing (Saarni, 1999, 2003; Weiner 2005). In other words, the development of competences in the area of visual arts education comprises the cognitive aspect:obtaining theoretical, conceptual, abstract knowledge (obtaining knowledge of visual arts theory, visual arts history and visual arts teaching methodology); the functional aspect (development of agility, skills and procedural knowledge possibility to recognise, shape and solve visual arts problems; skills in using art techniques); and the emotional-motivational and educational-socialisation aspect (esthetic sensitivity development, professional responsibility, autonomy and ethics) (Peklaj \& Puklek Lepušček, 2006; Pevec Grm \& Škapin, 2006).

To stimulate the pupils' creativity, teachers should be creative in their classes (Shepherd, 2005). In doing so, they should be familiar with and use modern, interactive approaches to learning and teaching, various teaching means and aids, including ICT technology; they should include their pupils in independent and active work, and stimulate their desire for new and different ways of solving visual arts problems (Tomljenović, 2015). Teachers should know the level of their pupils' previous knowledge and visual arts characteristics/visual arts types of pupils in order to prepare the teaching topics more successfully, to determine visual arts tasks, and to assess the pupils' artwork (Duncum, 1999). What is needed is the openness towards using new visual arts technique and their combinations, i.e., stimulating students to experiment with art techniques and materials since good educational work has a great impact on the forming part of the artistic development of pupils (Duh, Herzog, \& Gosak, 2011). The pupils' critical thinking, as well as the expression of their thoughts and associations, new and unusual ideas, unforeseen visual arts solutions and imagination, should be encouraged as a prerequisite for the development of creative thinking and expression. It is essential that teachers understand the teaching content and that they possess the ability to interpret it and connect it with other teaching contents and life situations (Atkinson, 2002; Bonwell, 2000; Hurwitz \& Day, 2007; Taylor, 2007).

The contemporary understanding of competences as developmental categories implies the teacher's care for his or her further training, i.e., lifelong education. Thus, it is crucial that a teacher, among other things, possesses the ability to recognise information from his or her surroundings which are essential for professional improvement, and the desire, i.e., the intrinsic motivation for lifelong learning, i.e., personal growth (Niemi \& Kohonen, 1995). L. Bognar and B. Bognar (2007) believe that the process of continuing education for teachers is as important as formal education if it is not reduced to authoritative over-teaching and giving instructions but represents a process in which 
teachers critically rethink their professional activity. Traditional professional development workshops should be replaced with an alternative professional learning context, an innovative learning environment (work-based learning) in which modern approaches to teaching and the strategies for their mastering in practice, which offer concrete and applicable solutions, will be demonstrated (Desimone, Porter, Garet, Yoon, \& Birman, 2002; Wilson \& Berne, 1999).

\section{Research problem and research questions}

In the context of the Bologna changes in higher education in Croatia, the study programmes of teachers' education are also changing and developing in all areas, including in visual arts education. Contemporary visual arts education places numerous tasks before primary school teachers for which they are not fully prepared during their formal education, although the existing subjects that comprise the visual arts area at the faculties of teacher education in Croatia are attempting to optimally satisfy the students' qualifications with their programmes. Research also shows that visual arts, as a subject, are often neglected in relation to the 'important'/educational subjects, and it is mostly seen as a 'non-cognitive', practical activity whose purpose is relaxation of pupils (Garvis \& Pendergast, 2012; Russel-Bowie, 2009, 2012; Tomljenović \& Novaković, 2014). The objective of the applied empirical research was to establish the final year student-teachers' and the in-service primary school teachers' opinions about the importance of having specific subject-specific competences and their own qualifications in the area of visual arts.

Apart from the main objective, the following specific research questions were established:

1) Which subject-specific competences in the area of visual arts do the students and teachers consider essential, and which do they think they possess?

2) Are there any statistically significant differences in the perception of the importance of certain subject-specific competences and the perception of possessing these competences between both groups (students and teachers)?

3) Within the visual arts area, in which areas would the students and teachers like to improve their levels of mastering subject-specific competences?

4) How often do the teachers participate in various forms of professional training in the area of visual arts? 


\section{Method}

\section{Sample}

A total of 231 students ( 12 male and 219 female) participated in the research. These respondents were student-teachers of the fourth and fifth year at the faculties of teacher education in Zagreb, Petrinja, Čakovec, and Rijeka (hereinafter: students). Furthermore, 143 in-service primary school teachers ( 2 male and 141 female) participated in the research (hereinafter: teachers). They were employed in the aforementioned cities and in Istria County. The participants were randomly selected. Teachers differ according to the degree of professional education: slightly over one half of the teachers $(55.9 \%)$ hold a two-year college degree while $44.1 \%$ hold a university degree. This difference is a consequence of the educational policy in the Republic of Croatia. Before the Bologna process, primary school teachers' education lasted two, then four years, and now, after the introduction of Bologna changes, graduate studies at Croatian universities last five years. A total of 118 respondents have the status of teacher $(82.5 \%)$ while 25 of them $(17.5 \%)$ have the status of mentor or counsellor. Most of the teachers (more than two thirds of the respondents) are middleaged (between 36 and 55 years of age), i.e., they have between 11 and 30 years of work experience. Slightly over one tenth of the respondents belong to the group whose age is less than 35 and another one tenth to the group whose age is over 55. The average age of the respondents is 45 .

\section{Data collection procedures and analysis}

Two questionnaires were designed for this research: one for the students of the faculties of teacher education, and one for the primary school teachers. The questionnaires contained close-ended questions. Both questionnaires had the first two questions in common: they referred to the perception of importance, i.e., to the degree in which the participants believe they possess the 25 stated subject-specific competences whose acquisition is needed to optimally carry out visual arts classes. In designing the list of competences, we acted in accordance with the curricula for visual arts and visual arts subjects at the faculties of teacher education in Croatia, and with some existing systematisations in the region (Tacol, 2006). The respondents assessed their own competences and qualifications on the basis of a Likert-type scale with five items. Apart from these, the questionnaire for the teachers contained two additional questions, and the questionnaire for the students one additional question. The research is based on a quantitative research paradigm. The data obtained by the questionnaires were processed at the level of descriptive and inferential statistics. 


\section{Results and discussion}

\section{Teachers' and students' perception of the importance of subject-specific competences and the level of their possession}

The results in Table 1 show the teachers' and students' perception of the importance of subject-specific competences, and the degree of their possession. Data are presented in terms of means (M) and standard deviations (SD). The perception of the importance of these competences was measured on a scale from 1 to 5 ( $1=$ not at all important, $2=$ slightly important; $3=$ moderately important; 4 = important; $5=$ very important).

Table 1

Descriptive features of specific competences importance evaluation in the visual arts area, and the assessment of possessing them on behalf of the teachers and students

\begin{tabular}{|c|c|c|c|c|c|}
\hline \multirow{2}{*}{ Competences } & \multirow{2}{*}{ Participants } & \multicolumn{2}{|c|}{ Importance } & \multicolumn{2}{|c|}{ Possession } \\
\hline & & $M$ & SD & $M$ & SD \\
\hline \multirow{2}{*}{$\begin{array}{l}\text { Knowledge of, understanding of and the use of the } \\
\text { visual arts language (visual arts elements and com- } \\
\text { positional principals) in visual arts classes }\end{array}$} & students & 4.52 & .638 & 3.87 & .664 \\
\hline & teachers & 4.34 & .742 & 3.69 & .899 \\
\hline \multirow{2}{*}{$\begin{array}{l}\text { Knowing, understanding, and applying basic visual } \\
\text { arts history/cultural heritage contents in visual arts } \\
\text { classes }\end{array}$} & students & 3.75 & .779 & 3.36 & .701 \\
\hline & teachers & 4.58 & .834 & 3.22 & .791 \\
\hline \multirow{2}{*}{$\begin{array}{l}\text { Knowing, understanding, and applying basic visual } \\
\text { communications and design contents in visual arts } \\
\text { classes }\end{array}$} & students & 4.05 & .654 & 3.43 & .782 \\
\hline & teachers & 3.91 & .638 & 3.33 & .862 \\
\hline \multirow{2}{*}{$\begin{array}{l}\text { Possessing aesthetic sensitivity for the works } \\
\text { of visual arts and the ability to choose them for } \\
\text { the methodological realisation of the visual arts } \\
\text { programme }\end{array}$} & students & 4.21 & .687 & 3.68 & .740 \\
\hline & teachers & 4.15 & .715 & 3.52 & .803 \\
\hline \multirow{2}{*}{$\begin{array}{l}\text { Knowledge of visual arts techniques in the drawing } \\
\text { area }\end{array}$} & students & 4.62 & .553 & 3.97 & .733 \\
\hline & teachers & 4.64 & .481 & 4.12 & .707 \\
\hline \multirow{2}{*}{$\begin{array}{l}\text { Knowledge of visual arts techniques in the painting } \\
\text { area }\end{array}$} & students & 4.63 & .559 & 3.97 & .739 \\
\hline & teachers & 4.62 & .488 & 4.13 & .711 \\
\hline \multirow{2}{*}{$\begin{array}{l}\text { Knowledge of visual arts techniques in three-dimen- } \\
\text { sional shaping area }\end{array}$} & students & 4.54 & .595 & 3.66 & .791 \\
\hline & teachers & 4.43 & .677 & 3.78 & .723 \\
\hline \multirow{2}{*}{$\begin{array}{l}\text { Knowledge of visual arts techniques in the graphics } \\
\text { area }\end{array}$} & students & 4.49 & .632 & 3.55 & .858 \\
\hline & teachers & 4.38 & .614 & 3.47 & .758 \\
\hline \multirow{2}{*}{$\begin{array}{l}\text { Knowing the process of visual perception and the } \\
\text { visual arts procedure, and the development of one's } \\
\text { own creative thinking and expression }\end{array}$} & students & 4.49 & .652 & 3.88 & 2.126 \\
\hline & teachers & 4.29 & .579 & 3.63 & .775 \\
\hline
\end{tabular}




\begin{tabular}{|c|c|c|c|c|c|}
\hline \multirow{2}{*}{ Competences } & \multirow{2}{*}{ Participants } & \multicolumn{2}{|c|}{ Importance } & \multicolumn{2}{|c|}{ Possession } \\
\hline & & $M$ & SD & $M$ & SD \\
\hline \multirow{2}{*}{$\begin{array}{l}\text { Knowledge and understanding of the visual arts } \\
\text { curriculum, and developing and executing the visual } \\
\text { arts curriculum in the class teaching }\end{array}$} & students & 4.41 & .666 & 3.73 & .863 \\
\hline & teachers & 4.25 & .622 & 3.78 & .764 \\
\hline \multirow{2}{*}{$\begin{array}{l}\text { Knowing the importance, purpose, goals, and results } \\
\text { of learning visual arts as a school subject }\end{array}$} & students & 4.46 & .630 & 3.93 & .777 \\
\hline & teachers & 4.45 & .590 & 4.09 & .759 \\
\hline \multirow{2}{*}{$\begin{array}{l}\text { The ability to independently programme, plan, orga- } \\
\text { nise and manage the teaching process, appreciating } \\
\text { the particularities of visual arts as a subject }\end{array}$} & students & 4.40 & .683 & 3.80 & .857 \\
\hline & teachers & 4.31 & .674 & 3.94 & .820 \\
\hline \multirow{2}{*}{$\begin{array}{l}\text { The ability to connect (correlate) the visual arts } \\
\text { contents with other areas/other school subjects on } \\
\text { the structural level }\end{array}$} & students & 4.34 & .679 & 4.02 & .704 \\
\hline & teachers & 4.39 & .531 & 4.29 & .680 \\
\hline \multirow{2}{*}{$\begin{array}{l}\text { Knowledge of and the ability to use various teach- } \\
\text { ing means and tools, and independently apply ICT } \\
\text { technology in visual arts classes }\end{array}$} & students & 4.24 & .698 & 3.97 & .804 \\
\hline & teachers & 4.01 & .569 & 3.70 & .823 \\
\hline \multirow{2}{*}{$\begin{array}{l}\text { Knowledge of contemporary strategies of indepen- } \\
\text { dent, active, and research learning and its applica- } \\
\text { tion within visual arts classes }\end{array}$} & students & 4.13 & .657 & 3.57 & .856 \\
\hline & teachers & 3.83 & .682 & 3.41 & .816 \\
\hline \multirow{2}{*}{$\begin{array}{l}\text { The ability to motivate students for visual arts } \\
\text { activities and stimulate their creative thinking and } \\
\text { expression }\end{array}$} & students & 4.69 & .550 & 4.15 & .739 \\
\hline & teachers & 3.83 & .682 & 3.41 & .816 \\
\hline \multirow{2}{*}{$\begin{array}{l}\text { Recognising and respecting children's visual arts } \\
\text { development, and adjusting the curriculum to stu- } \\
\text { dents' individual visual arts features }\end{array}$} & students & 4.63 & .582 & 3.88 & .851 \\
\hline & teachers & 4.53 & .528 & 3.86 & .737 \\
\hline \multirow{2}{*}{$\begin{array}{l}\text { Development of students' visual perception and } \\
\text { visual arts aesthetic sensibility }\end{array}$} & students & 4.48 & .603 & 3.71 & .827 \\
\hline & teachers & 4.31 & .536 & 3.88 & .736 \\
\hline \multirow{2}{*}{$\begin{array}{l}\text { Development of motor agility and students' } \\
\text { sensitivity through the use of different visual arts } \\
\text { techniques }\end{array}$} & students & 4.50 & .625 & 3.79 & .818 \\
\hline & teachers & 4.43 & .511 & 4.05 & .715 \\
\hline \multirow{2}{*}{$\begin{array}{l}\text { Developing students' recognition, understanding, } \\
\text { and using visual language on their own artworks, } \\
\text { works of visual arts, and in their own surroundings }\end{array}$} & students & 4.27 & .645 & 3.75 & .756 \\
\hline & teachers & 4.06 & .579 & 3.71 & .777 \\
\hline \multirow{2}{*}{$\begin{array}{l}\text { Developing cooperative relationships, empathy and } \\
\text { self-respect in joint activities and students' creative } \\
\text { work }\end{array}$} & students & 4.58 & .576 & 4.19 & .713 \\
\hline & teachers & 4.51 & .515 & 4.21 & .701 \\
\hline \multirow{2}{*}{$\begin{array}{l}\text { The ability to analyse children's artworks and to } \\
\text { objectively and critically evaluate students' achieve- } \\
\text { ments in visual arts classes }\end{array}$} & students & 4.46 & .573 & 3.99 & 2.143 \\
\hline & teachers & 4.47 & .501 & 3.94 & .714 \\
\hline \multirow{2}{*}{$\begin{array}{l}\text { The ability to reflect, i.e., knowing methodological } \\
\text { and professional criteria for rating one's own work } \\
\text { within visual arts classes }\end{array}$} & students & 4.24 & .582 & 3.56 & .837 \\
\hline & teachers & 4.15 & .585 & 3.73 & .619 \\
\hline \multirow{2}{*}{$\begin{array}{l}\text { Understanding and using appropriate procedures of } \\
\text { scientific-research work in the visual arts area }\end{array}$} & students & 3.72 & .770 & 3.04 & .922 \\
\hline & teachers & 3.63 & .689 & 2.98 & .884 \\
\hline \multirow{2}{*}{$\begin{array}{l}\text { Awareness about the importance of professional } \\
\text { training and lifelong education in the visual arts area }\end{array}$} & students & 4.08 & .715 & 3.76 & .876 \\
\hline & teachers & 4.17 & .605 & 4.10 & .695 \\
\hline
\end{tabular}

According to the respondents' assessment, almost all stated competences are important or very important, which suggests that the awareness of the 
respondents about the importance of the competence approach to the realisation of learning outcomes is high, as is the perception of the importance of visual arts education within the curriculum, regardless of its current status (reflected in the predetermined elementary school schedule of only one hour per week). The arithmetic mean of the stated items ranges from 3.72 (students)/3.59 (teachers) to 4.69 (students)/4.64 (teachers). The students assessed the following competences as being the most important: the ability to motivate the pupils for visual arts activities and to stimulate their creative thinking and expression; recognising and respecting the children's visual arts development, and adjusting the curriculum to the pupils' individual visual arts features (visual arts types); knowledge of visual arts techniques (in the drawing and painting areas, and in three-dimensional shaping area; knowledge of, understanding of and the use of the visual arts language (visual arts elements and compositional principals) in visual arts classes; development of cooperative relationships, empathy, and selfrespect in joint activities and the pupils' creative work. The students assessed the following competences as of least importance: knowledge, understanding and application of basic visual arts history/cultural heritage contents in visual arts classes; knowledge of, understanding and application of basic visual communications and design contents in visual arts classes; also, understanding of and using appropriate procedures of scientific research in visual arts. Teachers assessed as the most important competences similar variables as the students did: knowledge of visual arts techniques in the drawing and painting area; recognising and respecting the children's visual arts development, and adjusting the curriculum to the pupils' individual visual arts features; also, development of cooperative relationships, empathy and self-respect in joint activities and the pupils' creative work. In contrast, they assessed the same three variables as being of the least importance as the students did.

The results show that assessment of the importance of individual competences in both groups is relatively similar. Both groups of respondents consider most of the stated competences to be important. The following competences are perceived as the most important: knowledge of the visual arts language and visual arts techniques, knowledge of the children's visual arts development and visual arts types of pupils, and the development of cooperative relationships, empathy, and self-respect at work. The results are expected, as these competences form the foundation of the teaching process and the majority of teaching hours is devoted to their acquirement both at faculties and in professional training. Furthermore, classroom teaching (in Croatia, this term refers to the first four years of elementary education) is less demanding than teaching in higher classes, as older students are capable of understanding more abstract and complex contents, such 
as stylistic periods, contemporary art concepts, etc. However, such an approach can be criticised as an obsolete teaching approach, as these contents to a certain degree and with a customised approach can also be offered at a classroom level.

Competences that are perceived as the least important are related to the knowledge of visual arts history and visual communications, and those related to the knowledge of contemporary working strategies (independent, research learning, and implementing research activities on behalf of the teacher). We can note that these competences are 'the youngest', i.e., they have become a part of the Croatian faculty curricula in the last 10 to 20 years. For their effective understanding and implementation, students have to possess not only theoretical knowledge but much more practice organised outside the faculty classroom, i.e., in schools, which is, due to organisational and financial problems, a 'weak point' of all study programmes in Croatia. It is also not uncommon for some teachers and mentors in schools to teach visual arts in an established traditional way for students' practice exercises. For similar reasons, understanding of the role of teachers as researchers and active factors in changing traditional forms of education remains very poor for most existing but also future teachers. The greatest difference in assessing the importance between the two groups is noticeable in the ability to motivate the pupils to participate in visual arts activities and in the ability to stimulate their creative thinking and expression, which the students assessed as one of the most critical variables while the teachers assessed it as one of the least significant variables. The reasons for this can be found in the fact that these activities are a part of the usual process that teachers accomplish through their teaching activities, hence the abilities that they acquire and develop through their daily professional experience. However, it can be said that some teachers in the long term lose their freshness and creativity in the teaching process because of different factors (mostly because of the lack of time for a quality realization of visual arts classes). Students are, however, aware of the importance of these competences, as study programmes are based on modern approaches to learning and teaching.

The perception of the level of possession of subject-specific competences was measured on a scale from 1 to 5 ( $1=\mathrm{I}$ do not possess any; $2=\mathrm{I}$ possess them in a small amount; 3 = I partly possess them; 4 = I possess them to a greater degree; 5 = I fully possess them). Regarding the possession of specific competences, the arithmetic mean of the stated items ranges from 3.04 (students)/2.98 (teachers) to 4.19 (students)/4.29 (teachers). Students consider themselves most qualified in the area of developing cooperative relationships and empathy among pupils, in the correlation between visual arts contents and other subjects' contents, in the area of ICT technology usage and the use of other 
teaching means, and in the knowledge of the visual arts techniques of drawing and painting. Teachers consider themselves the most competent in the area of cross-curricular teaching (connecting visual arts contents with the contents of other school subjects), and in developing cooperative relations and empathy among pupils, as well as in the area of knowledge of the visual arts techniques of drawing and painting, in the area of motivating the pupils to engage in visual arts activities; also, in the area of knowledge of the importance, purpose, and goals of visual arts as a subject. It is interesting that, at the same time, the respondents consider the majority of the stated competences as being the most important. The assessment results of the least developed competences overlap in both groups: both the students and the teachers consider themselves the least competent in understanding and using appropriate procedures and scientific research, in the knowledge of visual arts history and visual communications (these competences are also considered as the least important), and in the use of graphic art techniques. This fact can be interpreted as follows: these contents are less represented in curricula (both in faculties and in primary and secondary schools); consequently, the students consider them to be less important; for the same reason, they are considered to be the least competent in the mentioned areas. Due to the limited number of hours foreseen for the content of visual arts education in the entire educational system, these contents should be given more attention when planning and implementing a lifelong learning programme for teachers. As far as the latter competence is concerned, the graphic art techniques are unfairly ignored in visual arts education, mostly because it takes more time for their use than for working with other common art techniques. However, today there are many new graphic art techniques adapted to school conditions but also a lack of professional literature that would bring them closer to a broader circle of employed teachers.

Furthermore, it is noticeable that the students give a somewhat greater importance than the teachers to all the stated competences; on the other hand, the teachers assess their possession of the stated competences to a somewhat greater degree, but not significantly greater (although, considering their years spent in service and experience, it is expected that this difference is even greater).

The teachers assess the level of competence possession equally as the students, or even somewhat higher, and assess the level of mastering these competences somewhat lower than the students in as many as ten variables. The reason for this could lie in the modernisation of the curricula at the faculties of teacher education, and the rise in the quality of their implementation in the didactic sense (the accent is on appreciating methodical particularities of visual arts teaching, basing classes on active, cooperative, and research-oriented 
learning, and stimulating intrinsic motivation, the application of contemporary work strategies, ICT technology, etc.), but also in inadequately following modern trends in the educational work of teachers who possess much more experience in the application of demanding theoretical concepts in practice.

The analysis of the results has established a difference in the perceptions of the importance and the level of possession of specific competences between students and teachers, which builds on the results of some other studies in this area (Oreck, 2004; Welch, 1995). A Wilcoxon Signed Ranks Test was used to compare the differences in the arithmetic means between the perception of importance and the perception of possessing the competences between these two groups since the variables are continuous and normally distributed. For the purpose of this research, summation variables were designed so that the arithmetic mean of the importance assessment of all 25 competences is summarised in the group result, i.e., in one variable. This was also done with the assessment of the level of the possession of specific competences.

Table 2

Results of the Wilcoxon Signed Ranks Test of the comparison of the subjectspecific competences importance assessment and the perception of possessing the same competences for students and teachers

\begin{tabular}{cccccccc}
\hline & \multicolumn{3}{c}{ Importance } & \multicolumn{2}{c}{ Possession } & \multicolumn{2}{c}{$\begin{array}{c}\text { Wilcoxon Signed } \\
\text { Ranks Test }\end{array}$} \\
\cline { 2 - 8 } & $\mathbf{N}$ & $\mathbf{M}$ & SD & M & SD & Z & p \\
\hline Students & 231 & 4.356 & .346 & 3.768 & .517 & -11.550 & .001 \\
Teachers & 143 & 4.259 & .309 & 3.783 & .555 & -8.312 & .001 \\
\hline
\end{tabular}

Note. Correlation is significant at the .01 level (2-tailed).

The analysis of the results has shown a statistically significant difference between the perception of the importance and the perception of the level of possessing subject-specific competences, both in students $(Z=-11.550, p=.001)$ and in teachers $(Z=-8.312, p=.001)$ (Table 2$)$. It was found that the perception of the importance of certain competences both in students and in teachers is significantly higher than the perception of their possession level. From this, we can infer that the students' possession of the stated competences in the area of visual arts education after graduation is not satisfactory, as well as the fact that the teachers make little progress during their professional development in this area. The reasons for this may be different: a small number of hours at the faculties foreseen for visual arts education, the outdated approach to learning and teaching (the emphasis is 
on the acquisition of theoretical knowledge, instead of the acquisition of practical knowledge and skills), financial and organisational problems in schools (too many pupils in classes, too little time (only one hour per week for visual arts) for the quality implementation of teaching contents provided by the curriculum, lack of appropriate teaching and technical resources, lack of support from colleagues, etc.). These factors can cause a loss of enthusiasm, motivation and self-confidence in teachers' professional work. They also indicate the constant need to modernise teachers' professional development programmes, which should be planned based on the relevant research and teachers' actual needs and interests.

\section{Perception of visual arts areas in which students and teachers would like to acquire additional knowledge and skills}

Apart from the stated questions, the teachers' and students' questionnaires also included a question about specifying those areas within visual arts education that should be given more attention at the faculty, i.e., in planning professional teacher training.

Table 3

Perception of the areas of visual arts within which teachers and students would like to improve their level of mastering subject-specific competencies

\begin{tabular}{lcccc}
\hline & \multicolumn{2}{c}{ students } & \multicolumn{2}{c}{ teachers } \\
\cline { 2 - 5 } & $\mathrm{f}$ & $\%$ & $\mathrm{f}$ & $\%$ \\
\hline Use of visual arts techniques and visual arts-creative expression & 118 & 51.1 & 108 & 75.5 \\
$\begin{array}{l}\text { Development of aesthetic sensibility and the ability to analyse } \\
\text { works of art }\end{array}$ & 117 & 50.6 & 76 & 53.1 \\
$\begin{array}{l}\text { Specificities of didactic and methodological procedures of } \\
\text { organising and executing classes }\end{array}$ & 114 & 49.4 & 62 & 43.4 \\
$\begin{array}{l}\text { Connecting visual arts content with contents of other subjects } \\
\text { Subject content (visual arts theory, visual arts history, cultural }\end{array}$ & 69 & 29.9 & 20 & 14.0 \\
heritage) & 50 & 21.6 & 18 & 12.6 \\
Nothing needs changing & 7 & 3.0 & 3 & 2.1 \\
\hline Total & 231 & 100 & 143 & 100 \\
\hline
\end{tabular}

The results show that students and teachers have similar priorities in gaining subject-specific competences. Both would like to improve their abilities in using visual arts techniques, and especially their visual arts creative expression (up to $75 \%$ of teachers and $51.1 \%$ of students) (Table 3 ). This finding is interesting since this area (drawing and painting art techniques) is given the highest rate when assessing the importance and possession in both groups and can 
be interpreted as a consequence of priority interest that students and teachers show precisely for using visual arts techniques, i.e., practical work with pupils. This result can be a consequence of the popular, but also the obsolete and prevailing concept of visual arts education as a primarily practical activity whose main goal is to relax the pupils through art expression. The results may also indicate a desire for the better mastering of the use of three-dimensional art techniques and graphic art techniques, as those areas for which the respondents feel less competent. The second area in importance, to which, according to the students, not enough attention is given during the studies, is the development of aesthetic sensibility and the ability to analyse artworks (50.6\%). This is followed by the area connected with the specificities of didactic and methodical procedures of organising and executing the teaching process (49.4\%). Similar results are found with teachers: $53.1 \%$ would like to gain additional competences related to didactic and methodical procedures and organisation and execution of teaching while $43.4 \%$ assess they need additional knowledge and abilities connected with aesthetic sensibility growth and artworks analysis. The area in which the teachers and the students feel the least desire to receive additional training is visual arts theory and visual arts history and the area of connecting visual arts content with other areas. The placement of competences connected with the area of visual arts theory, visual arts history and cultural heritage at the end of the table could be linked to poor rating of these variables in terms of importance, but also possession, which can be interpreted by the fact that the respondents consider these components in visual arts teaching to be less important, so they want the least additional training in this area. The assumption is that students and teachers also have the least desire to be additionally educated in connecting visual arts with other areas, because the possession of this competence is assessed with the highest rates by both students and teachers, i.e., the respondents consider that they possess it to a higher degree.

\section{Teachers' professional training in the visual arts}

The aim of this research was also to determine how often the teachers participate in some form of professional training in visual arts throughout their career. The greatest number of respondents, almost half of them, have participated in some form of professional training in the context of visual arts teaching between three and five times; about one fourth of the teachers have participated once or twice, around one sixth of the participants between five and ten times, while an equal percentage of the respondents have participated in professional training more than ten times and have never participated (6.3\%). Considering that the average age of the respondents is 45 , it can be concluded that teachers 
do not participate often enough in any of the forms of professional training which are connected to visual arts teaching. One of the reasons for this most probably lies in the rare occurrence of professional training in this area. On the other hand, as stated earlier, visual arts education is considered peripheral to other 'important' subjects (mathematics, mother tongue, foreign language), which can weaken the teachers' perceptions about the importance of art education in general (Welch, 1995), as well as their motivation for gaining further professional training in this area. Furthermore, the opinion that continues to prevail in Croatian education is that the subject of visual arts is mostly practical in nature and, especially in the realm of class teaching, considers its main role to be pupils' relaxation with the lowest degree of teacher's influence or his/her interaction with the pupils. This perception could also be associated with the very poor presence of the visual arts in the Croatian curriculum, which is only one lesson per week, or 35 lessons per year, in all grades of primary school. The results can also indicate the teachers' insufficient awareness of the importance of further professional education after graduation from their faculties.

Table 4

Frequency of teachers' professional training in the context of visual arts education

\begin{tabular}{lcc}
\hline & f & \% \\
\hline never & 9 & 6.3 \\
once to twice & 35 & 24.5 \\
3 to 5 times & 69 & 48.3 \\
5 to 10 times & 21 & 14.7 \\
more than 10 times & 9 & 6.3 \\
\hline Total & 143 & 100 \\
\hline
\end{tabular}

\section{Conclusions}

The possession of subject-specific competences in the visual arts is a prerequisite for the quality implementation of visual arts classes (Prentice, 2002; Tacol, 2007). The conducted research examined the assessment of these competences among students in their final years of study at faculties of teacher education, as well as among in-service primary school teachers. The assessment of their own qualification in the context of the stated competences was also examined. The analysis of the results has shown that both the students and the teachers consider subject-specific competences in the visual arts area to be important or very 
important. The results, however, also indicate the fact that the respondents possess the given competences only partly or to a lesser degree. On the one hand, this is understandable since the students of the faculties of teacher education are educated in several areas, i.e., they need to master contents and didactic and methodological knowledge in six basic areas/school subjects that they will be teaching in school (Croatian, maths, science, physical education, music, visual arts), and because of this they cannot engage in a detailed training in the sense of optimal acquisition of all stated competences. In contrast, this fact might also indicate insufficiently elaborated programmes that need to be changed in order to achieve better methodical and practical qualifications, i.e., programmes that should dedicate more time to practical exercise with appreciating contemporary approaches to learning and teaching. The findings of this study have confirmed some of the problems that teachers from other countries also encounter, and they relate to the question of whether the expectations of a primary school teachers' subject knowledge are too high, and in what way the balance between the demands of mastering particular methodologies and the abilities to understand and successfully realise their contents in school practice could be achieved (Alter, Hays, \& O'Hara, 2009). According to some research (Russel-Bowie, 2009), it appears that, because of the study programme's demands, visual arts teaching is one of the areas which suffers the most from the lack of subject-specific knowledge and skills acquirement; i.e. during the studies, as well as in teaching, more time is dedicated to 'more important' subjects such as maths, mother tongue and foreign languages. This research suggests the need for continuous monitoring and modernisation of the existing curricula in order to ensure the conditions for optimal acquisition of necessary subject-specific competences for all students. In addition, the results also show an insufficient presence of professional training in the visual arts area. So, it would be interesting to examine the reasons for which teachers rarely participate in professional training programmes in the visual arts area. In order to improve the existing status, it is necessary to establish better cooperation between faculties of teacher education and educational institutions, which are directly or indirectly connected with teachers' professional training and professional development, with the goal of improving professional betterment and life-long learning, which will, among other things, be related to the research of specific professional and methodical areas of particular subjects, such as visual arts education.

Given the fact that the issue of subject-specific competences in visual arts education has not been explicitly studied yet in Croatia (and abroad), we have attempted to contribute with this paper to the research field while being aware of the fact that we have implicitly opened new questions that may be the subject of further studies. 


\section{References}

Alter, F., Hays, T., \& O’Hara, R. (2009). Creative arts teaching and practice: Critical reflections of primary school teachers in Australia. International Journal of Education \& the Arts, 10(9), 1-21. Atkinson, D. (2002). Art in education: Identity and practice. Dordrecht: Kluwer Academic Publishers. Barton, G. M., Baguley, M., \& MacDonald, A. (2013). Seeing the bigger picture: Investigating the state of the arts in teacher education programs in Australia. Australian Journal of Teacher Education, $38(7)$, 75-90. Retrieved from http://ro.ecu.edu.au/cgi/viewcontent.cgi? article=2106\&context=ajte Bamford, A. (2006). The wow factor: Global research compendium on the impact of the arts in education. Berlin: Waxmann.

Bognar, L., \& Bognar, B. (2007). Kreativnost učitelja kao značajna kompetencija nastavničke profesije [Teachers creativity as a significant competence of the teaching profession]. In N. Babić (Ed.), Kompetencije i kompetentnost učitelja (pp. 96-115). Osijek: Učiteljski fakultet Sveučilišta Josipa Jurja Strossmayera u Osijeku.

Bonwell, C. C. (2000). Active learning: Creating excitement in the classroom. Washington, DC: The George Washington University.

Burnard, P., \& Hennessy, S. (Eds.) (2006). Reflective practices in arts education. Dordrecht: Kluver. Craft, A. (2000). Continuing professional development: A practical guide for teachers and schools. London, UK: Routledge.

Desimone, L. M., Porter, A. C. Garet, M. S. Yoon, K. S., \& Birman, B. F. (2002). Effects of professional development on teachers' instruction: Results from a three-year longitudinal study. Educational Evaluation and Policy Analysis, 24(2), 81-112.

Domović, V., \& Vizek Vidović, V. (2010). Developing a quality culture in initial teacher education in Croatia. In B. Hudson, P. Zgaga, \& B. Astrand (Eds.), Advancing quality cultures for teacher education in Europe (pp. 105-121). Umea: Umea School of Education, Umea University.

Duh, M., Hezog, J., \& Gosak, L. (2011). The role of using art techniques for teaching art and design strategies to primary school children. Journal of Elementary Education, 4(1-2), 61-8o.

Duncum, P. (1999). What elementary generalist teachers need to know to teach art well. Art

Education, 52(6), 33-37.

Efland, A. D. (2002). Art and Cognition: Integrating the visual arts in the curriculum. New York, NY:

Teachers College Press, Columbia University \& National Art Education Association.

Eisner, E. W. (2002). What can education learn from the arts about the practice of education? Journal of Curriculum and Supervision, 18(1), 4-16.

Garvis, S., \& Pendergast, D. (2012). Storying music and the arts education: The generalist teacher voice. British Journal of Music Education, 29(1), 107-123.

Hudson, P. B., \& Hudson. S. M. (2005). Examining preservice primary teachers' potential for teaching art in primary schools. Retrieved from http://eprints.qut.edu.au/359o/1/359o.pdf Hudson, P., \& Hudson, S. (2007). Examining preservice teachers' preparedness for teaching art. International Journal of Education \& the Arts, 8(5), 1-24. Retrieved from http://ijea.asu.edu/v8n5/ 
Hurwitz, A., \& Day, M. (2007). Children and their art: Methods for the elementary school. Belmont,

CA: Thomson Higher Education.

Kowalchuk, E. A. (1999). Perceptions of practice: What art student teachers say they learn and need to know. Studies in Art Education, 41(1), 71-90.

Marshall, J. (2005). Connecting art, learning, and creativity: A case for curriculum integration.

Studies in Art Education, 46(3), 227-241.

Muršak, J. (2001). Kompetence kot osnova razvoja sodobnih sistemov poklicnega izobraževanja

[Competencies as the basis for the development of modern vocational education systems]. Sodobna pedagogika, 52(4), 71-82.

Niemi, H., \& Kohonen, V. (1995). Towards new professionalism and active learning in teacher development: Empirical findings on teacher education and induction. Tampere: University of Tampere.

Oreck, B. (2004). The artistic and professional development of teachers. Journal of Teacher Education, 55(1), 55-69.

Peklaj, C., \& Puklek Lepušček, M. (2006). Pridobljene in želene učiteljske kompetence diplomantov in študentov Filozofske fakultete [Acquired and desired teachers' competencies of graduates and students of the Faculty of Arts]. In C. Peklaj (Ed.), Teorija in praksa v zobraževanju učiteljev (pp. 29-43). Ljubljana: Center za pedagoško izobraževanje, Filozofska fakulteta, Univerza v Ljubljani. Pevec Grm, S., \& Škapin, D. (2006). Kurikul na nacionalni in šolski ravni v poklicnem in strokovnem izobraževanju [Curriculum at national and school level in vocational and professional education]. Ljubljana: Center republike Slovenije za poklicno izobraževanje.

Podobnik, U. (2011). Percepcija likovne umetnine in načrtovanje likovne dejavnosti v šoli [Perception of artwork and planning of visual arts classes at school]. In V. M. Kolar, B. Sicherl Kafol, \& D. Skribe Dimec (Eds.), Specialne didaktike: kaj nas povezuje in kaj ločuje (pp. 51-66). Ljubljana: Pedagoška fakulteta.

Prentice, R. (2002). Preparing primary teachers to teach art and design effectively. International Journal of Arts and Design Education, 21(1), 72-81.

Razdevšek Pučko, C., \& Rugelj, J. (2006). Kompetence v izobraževanju učiteljev [Competencies in teacher education]. Vzgoja in izobraževanje, 37(1), 34-41.

Russell-Bowie, D. E. (2009). Syntegration or disintegration? Models of integrating the arts across the primary curriculum. International Journal of Education \& the Arts, 10(28). Retrieved from http:// www.ijea.org/v1on28/

Russell-Bowie, D. E. (2012). Developing preservice primary teachers' confidence and competence in arts education using principles of authentic learning. Australian Journal of Teacher Education, 37(1), $60-74$.

Saarni, C. (1999). The development of emotional competence. New York, NY: Guilford Press.

Shepherd, D. (Ed.) (2005). Creative engagements: Thinking with children. Oxford, UK: InterDisciplinay Press.

Tacol, T. (2006). Izgrajevanje kompetenc - izhodišče za kakovostno poučevanje pri likovni dejavnosti [Building competencies - a starting point for quality teaching in visual arts education]. In S. Tancig 
\& T. Devjak (Eds.), Prispevki k posodobitvi pedagoških študijskih programov (pp. 170-191). Ljubljana: Pedagoška fakulteta Univerze v Ljubljani.

Tacol, T. (2007). Creative lessons of visual art education. Bratislava: Digit.

Taylor, E. W. (2007). An update of transformative learning theory: A critical review of the empirical research (1999-2005). International Journal of Lifelong Education, 26(2), 173-191.

Tomljenović, Z. (2015). An interactive approach to learning and teaching in visual arts education. CEPS Journal, 5(3), 75-95.

Tomljenović, Z., \& Novaković, S. (2014). Mišljenja učitelja razredne nastave o učenju i poučavanju likovne kulture u osnovnoj školi [Class teachers' opinions about learning and teaching visual arts in elementary school]. Inovacije u nastavi, 27 (2014), 1, 31-41.

Valenčič Zuljan, M. (2001). Modeli in načela učiteljevega profesionalnega razvoja [Models and principles of teachers' professional development]. Sodobna pedagogika, 52(2), 122-141.

Vizek Vidović, V. (2009). Model razvoja kurikuluma usmjerenog na kompetencije [A model of competency-oriented curriculum development]. In V. Vizek Vidović (Ed.), Planiranje kurikuluma usmjerenog na kompetencije u obrazovanju učitelja i nastavnika (pp. 67-75). Zagreb: Filozofski i Učiteljski fakultet Sveučilišta u Zagrebu.

Weiner, B. (2005). Motivation from an attribution perspective and the social psychology of perceived competence. In A. J. Elliot \& C. S. Dweck (Eds.), Handbook of competence and motivation, (pp. 73-84). New York, NY: Guilford.

Welch, A. (1995). The self-efficacy of primary teachers in art education. Issues in Educational Research, 5(1), 71-84.

Wilson, S. M., \& Berne, J. (1999). Teacher learning and the acquisition of professional knowledge: An examination of research on contemporary professional development. Review of Research in Education, 24, 173-209.

Zgaga, P. (2007). Prenova izobraževanja učiteljev v vetrovih evropskih reform visokega šolstva [Renovation of teacher education in the context of European higher education reforms]. In T. Devjak \& P. Zgaga (Eds.), Prispevki k posodobitvi pedagoških študijskih programov II (pp. 9-35). Ljubljana: Pedagoška fakulteta. 


\section{Biographical note}

Zlata Tomljenović, $\mathrm{PhD}$ in Art Education, Assistant Professor at the Faculty of Teacher Education, University of Rijeka, Croatia. Her main research topics concern student teachers' and teachers' general and subject-specific competences, teachers' professional development, interactive learning and teaching, teaching and learning strategies and methods in the context of visual arts education. She also participates in exhibitions and art symposiums at home and abroad.

Svetlana Novaković, PhD in Art Education. She works as a lecturer at the Chair of Arts at the Faculty of Teacher Education, University of Zagreb, Petrinja Branch. Her research field is focused on educating preschool teachers in art-pedagogic work. Beside doing research, she engages in art creation graphics. She leads art workshops for preschool and school children. 